\title{
The time of the first transition of the semi-Markov process in the evaluation of diesel engine operation
}

\begin{abstract}
The paper presents the extension of the method discussed in the literature of quantitative evaluation of operation on the example of a marine engine. According to this interpretation, the engine operation can be shown as a physical quantity. In this aspect, based on the main marine diesel engine an evaluation of the usefulness of this index for the description of the engine reliability related properties has been performed.

Apart from the generally used reliability indexes, it seems purposeful to consider the engine operation (as well as its functional subsystems) in the evaluative way, so that it could be described by both energy and time.

In this aspect, in the analysis the semi-Markov processes theory was used that allowed a description of the concept of the model of the engine deterioration process as a random one. The problem of the time of the first transition of the semi-Markov process to a subset of specified classes of states representing particular technical and reliability-related states of engine was described in detail.
\end{abstract}

Key words: operation, diesel engine, semi-Markov process

\section{Czas pierwszego przejścia procesu semi-Markowa w ocenie działania silnika z zapłonem samoczynnym}

\begin{abstract}
W artykule przedstawiono rozwinięcie prezentowanej w literaturze metody ilościowej oceny działania na przykładzie okrętowego silnika głównego z zapłonem samoczynnym. Wedlug tej interpretacji działanie silnika może być przedstawione jako wielkość fizyczna. W tym aspekcie, na przykładzie okrętowego silnika napędu głównego dokonano oceny przydatności tej wielkości do opisu wtaściwości niezawodnościowych silnika.

Oprócz powszechnie stosowanych wskaźników niezawodnościowych sensowne wydaje się rozpatrywanie działania silnika (jego podsystemów funkcjonalnych) w takim ujęciu wartościujacym, aby mogło ono być określone jednocześnie przez energię i czas.

$W$ tym aspekcie $w$ przeprowadzonej analizie wykorzystano teorię procesów semi-markowskich, która umożliwiła opracowanie propozycji modelu przebiegu pogarszania działania silnika, jako procesu losowego. Szczegółowo opisano problem czasu pierwszego przejścia procesu semi-Markowa do podzbioru wyodrębnionych klas stanów reprezentujących określone stany techniczne i niezawodnościowe silnika.
\end{abstract}

Słowa kluczowe: działanie, silnik z zapłonem samoczynnym, proces semi-Markowa

\section{Introduction}

Objectivity and rationality when making a decision assumed as optimum under given conditions forces a quantitative approach towards that issue thus it forces a search for such mathematical models and their parameters (indexes) that can be deemed as most adequate under a given decisionmaking situation.

In practice, the forecasts related to the realized tasks are based on a widely understood term of reliability of the operated object or system. When considering the term of reliability of energy-related devices (marine piston engines) we need to draw our attention to the fact that from the point of view of the end user the most vital issue is the quality performance of a given task (in an extreme case non-performance of the task). Hence, the term of reliability is tightly associated with a clear determination of this task.

A precise determination of the task, apart from the assumption of the conditions under which it is to be performed, requires an assumption of its duration. This task is particularly vital in such field as sea transport where the specificity of the tasks is usually related to the necessity of

\section{Wprowadzenie}

Obiektywność i racjonalność podczas wyboru decyzji uznanej za optymalną $\mathrm{w}$ danych warunkach wymusza wartościujące (ilościowe) podejście do tego zagadnienia, a tym samym poszukiwanie takich modeli matematycznych i ich parametrów (wskaźników), które w danej sytuacji decyzyjnej mogą być uznane za najbardziej adekwatne.

W praktyce prognozy dotyczące realizowanych zadań najczęściej bazują na szeroko rozumianym określeniu niezawodności eksploatowanego obiektu czy systemu. Rozpatrując z kolei pojęcie niezawodności urządzeń energetycznych (np. okrętowych tłokowych silników spalinowych), należy zwrócić uwagę na to, iż z punktu widzenia użytkownika najistotniejszym zagadnieniem jest jakość wykonania określonego zadania (w skrajnym przypadku niewykonanie zadania). Tym samym pojęcie niezawodności nierozerwalnie skojarzone jest z jednoznacznym określeniem tego zadania.

Z kolei precyzyjne określenie zadania wymaga, oprócz założenia warunków, w których będzie wykonywane, sprecyzowania również jego czasu trwania. Zagadnienie 
a long life functioning of the basic mechanisms and devices (a vessel).

That is why particularly important becomes not only the value of energy that is at our disposal when using the device but also the time in which it will be supplied.

Further considerations are limited to an individual example of the main marine engine.

Apart from generally applied reliability indexes it seems purposeful to consider the engine operation (its functional subsystems) in such an evaluative approach for it to be determined by energy and time simultaneously.

Action (D) in time range $[0, t]$ can in this case be interpreted as a physical quantity determined by the product of the energy variable in time $\mathrm{E}=\mathrm{f}(\mathrm{t})$ and time, which could generally be expressed by the following dependence [1]:

$$
\mathrm{D}(\mathrm{t})=\int_{0}^{\mathrm{t}} \mathrm{E}(\tau) \mathrm{d} \tau
$$

In the general considerations the introduction of the terms of:

- Required action $-\mathrm{D}_{\mathrm{w}}$, one that is necessary for the realization of the task (transport task for example-carrying cargo by sea in a given time - which is maintaining a given average speed hence the power output of the main marine engine(s)),

- Possible action $-\mathrm{D}_{\mathrm{M}}$, one that can be realized if the engine is in a given technical condition or works under specified conditions of operation,

We obtain a criterion of evaluation of the level of usability according to the rules set forth in detail in [4] through a verification of relation (1):

$$
\mathrm{D}_{\mathrm{M}} \geq \mathrm{D}_{\mathrm{W}}
$$

As the time elapses in the engine life cycle due to the deterioration processes the engine overall efficiency, defined as:

$$
\eta_{\mathrm{e}}=\frac{1}{\mathrm{~g}_{\mathrm{e}} \cdot \mathrm{w}_{\mathrm{d}}}
$$

where: $\mathrm{g}_{\mathrm{e}}$ - unit fuel consumption, $\mathrm{w}_{\mathrm{d}}-$ fuel calorific value, is reduced, which obviously results in changes of the previously defined value of the possible action $-\mathrm{D}_{\mathrm{M}}$.

In the case of the main marine engine due to a consideration of the high sea margin on the design stage and operating power reserve for an engine operated at part loads, the process of engine available power decrease (possible action $\mathrm{D}_{\mathrm{M}}$ ) will proceed in two stages:

- In the first stage only the increase on the hourly fuel consumption will take place (at a relatively steady value of the torque), hence the costs of operation will grow,

- In the second stage due to design limitations and impossibility of increasing of the fuel dose a reduction of the usable power will occur.

The described phenomena are caused by the adjustive action of the fuel system, that in a given range of values will increase the instantaneous fuel dose $-\mathrm{g}_{\mathrm{pi}}{ }^{\%}\left(\mathrm{~g}_{\mathrm{pi}}{ }^{\%}-\right.$ fuel does for $i \%$ of the engine load in a state of full operativeness; to jest szczególnie istotne w takich dziedzinach, jak np. transport morski, gdzie specyfika zadań z reguły związana jest z koniecznością długotrwałego funkcjonowania zasadniczych mechanizmów i urządzeń (np. statku). Tym samym szczególnie istotne staje się nie tylko to, jaka jest wartość energii, którą można dysponować użytkując dane urządzenie energetyczne, lecz także czas, w którym może być ona dostarczona.

Dalsze rozważania ograniczone są do konkretnego przykładu okrętowego silnika napędu głównego.

Oprócz powszechnie stosowanych wskaźników niezawodnościowych istotne wydaje się rozpatrywanie działania silnika (jego podsystemów funkcjonalnych) w takim ujęciu wartościującym, aby mogło ono być określone jednocześnie przez energię i czas.

Działanie (D) w przedziale czasu [0, t] może w tym przypadku być interpretowane jako wielkość fizyczna określona iloczynem energii zmiennej w czasie $E=f(t)$ i czasu, co można ogólnie wyrazić zależnością (1) [1].

Wprowadzając w ogólnych rozważaniach pojęcia:

- działania wymaganego - $\mathrm{D}_{\mathrm{w}}$, a więc takiego, które jest niezbędne do realizacji zadania (np. zadania transportowego, czyli przewozu ładunku drogą morską w określonym czasie - co jest jednoznaczne z utrzymaniem określonej średniej prędkości statku, a więc i mocy rozwijanej przez silnik(i) napędu głównego),

- działania możliwego - $\mathrm{D}_{\mathrm{M}}$, a więc takiego, które silnik, będący w określonym stanie technicznym i w określonych warunkach funkcjonowania, może zrealizować,

uzyskuje się w wyniku sprawdzenia relacji (1) - równanie (2) kryterium oceny stopnia zdatności, według zasad szczegółowo przedstawionych w pracy [4].

Wraz z upływem czasu podczas funkcjonowania silnika wskutek przede wszystkim degradacyjnego oddziaływania procesów zużycia jego sprawność ogólna, zdefiniowana np. w postaci równania (3), gdzie: $\mathrm{g}_{\mathrm{e}}-\mathrm{jed}$ nostkowe zużycie paliwa, $\mathrm{w}_{\mathrm{d}}$ - wartość opałowa dolna paliwa, zmniejsza się, co powoduje oczywiście zmiany w odniesieniu do wartości zdefiniowanego uprzednio działania możliwego $\mathrm{D}_{\mathrm{M}}$.

Dla napędu głównego silnika okrętowego, z powodu uwzględnienia w czasie projektowania znacznego tzw. marginesu morskiego oraz zapasu mocy eksploatacyjnej dla silnika użytkowanego na obciążeniach częściowych, proces zmniejszania mocy dysponowanej (a więc i działania możliwego $\mathrm{D}_{\mathrm{M}}$ ) przebiegać będzie w dwóch etapach:

- w pierwszym następować będzie wyłącznie wzrost godzinowego zużycia paliwa (przy względnie stałej wartości rozwijanego momentu obrotowego), a tym samym wzrosną koszty użytkowania,

- w drugim na skutek ograniczeń konstrukcyjnych i braku możliwości zwiększenia dawki paliwa pojawi się ograniczenie w wartości mocy użytecznej rozwijanej przez silnik. 
assuming that the maximum admissible engine load is $110 \%$ of the nominal load $-\mathrm{i} \leq 110$ ) until the engine reaches the maximum value $-\mathrm{G}_{\mathrm{pmax}}$. Each further reduction of the value of the overall engine efficiency will results in a drop of the engine power output.

\section{The application of the theory of semi-Markov processes for the evaluation of engine operation}

Keeping the above presented phenomena in mind and assuming the trueness of the following hypothesis that:

,the process of engine deterioration (understood as a random function, whose argument is time and the variables are random variables that at the same time denote their technical and energy related conditions) is a process whose state analyzed at any given moment $t_{n}(n=0,1, \ldots, m$; $t_{0}<t_{1}<\ldots<t_{m}$ ) depends on the state that directly precedes it and does not stochastically depend on the previous states and their durations"

it becomes possible to develop a mathematical models used in the evaluative description of the engine operation with the use of the semi-Markov processes [3].

The example of the $\{\mathrm{W}(\mathrm{t}): \mathrm{t} \in \mathrm{T}\}$ process realization has been presented in Fig. 1 .

The graph of engine states - the transitions of the discussed process $\{\mathrm{W}(\mathrm{t}): \mathrm{t} \in \mathrm{T}\}$ including the above described phenomena of fuel dose and power output changes can be presented as follows:

Hence, function matrix $\mathrm{Q}_{\mathrm{ij}}(\mathrm{t})$ of the process under discussion has the following form (as results from Fig. 2):

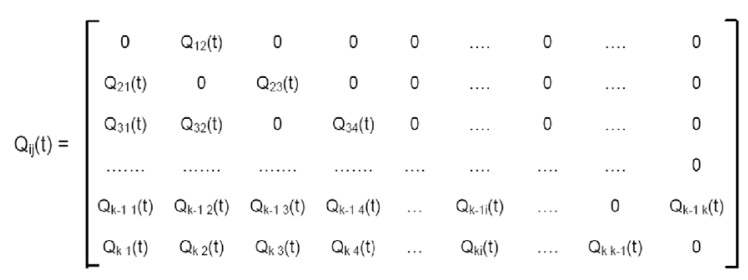

The elements of this matrix depend on the distribution of the random variables that are the durations of the processes in the distinguished states as follows:

$$
\begin{aligned}
& Q_{i j}(t)=P\left\{W\left(\tau_{n+1}\right)=s_{j}, \tau_{n+1}-\tau_{n}<t W\left(\tau_{n}\right)=s_{i}\right\} \\
& =p_{i j} \cdot F_{i j}(t) ; s_{i}, s_{j} \in S ; i, j=1,2, \ldots, k ; i \neq j
\end{aligned}
$$

where: $p_{i j}$ - probability of transition from state $s_{i}$ to state $s_{j}$, $F_{i j}(t)$ - distribution function of the random variable $T_{i j}$, that is the duration of state $s_{i}$ on conditions of passing of the process into state $s_{j}$.

Initial distribution of the process:

$$
\begin{gathered}
\mathrm{p}_{\mathrm{i}}=\mathrm{P}\left\{\mathrm{W}(0)=\mathrm{s}_{\mathrm{i}}\right\}, \\
\mathrm{s}_{\mathrm{i}} \in \mathrm{S} ; \mathrm{i}=1,2,3,4, \ldots, \mathrm{k}
\end{gathered}
$$

can be assumed depending on an individual task related situation, for example, the case of engine analysis in the state of full operativeness and usability:
Opisane zjawiska spowodowane są regulacyjnym oddziaływaniem aparatury paliwowej, która w określonym przedziale wartości będzie zwiększać chwilową dawkę paliwa $-\mathrm{g}_{\mathrm{pi}} \%\left(\mathrm{~g}_{\mathrm{pi}} \%\right.$ - dawka paliwa dla $\mathrm{i} \%$ obciążenia silnika $\mathrm{w}$ stanie sprawności technicznej; zakładając np., że maksymalne dopuszczalne obciążenie silnika wynosi $110 \%$ obciążenia nominalnego - $\mathrm{i} \leq 110$ ) aż do momentu osiągnięcia jej maksymalnej wartości $-\mathrm{G}_{\text {pmax }}$. Każde następne zmniejszenie wartości sprawności ogólnej silnika spowoduje rejestrowalny spadek mocy silnika.

\section{Zastosowanie teorii procesów semi-markowskich w ocenie dzialania}

Mając na uwadze przedstawione wyżej zjawiska oraz przyjmując, za prawdziwą następującą hipotezę: „proces degradacji stanu technicznego silnika (rozumiany jako funkcja losowa, której argumentem jest czas, a wartościami zmienne losowe, oznaczajace istniejace równocześnie stany techniczne i energetyczne silnika) jest procesem, którego stan rozpatrywany $w$ dowolnej chwili $t_{n}\left(n=0,1, \ldots, m ; t_{0}<t_{1}<\right.$ $\ldots<t_{m}$ ) zależy od stanu bezpośrednio go poprzedzającego $i$ nie zależy stochastycznie od stanów, które zaszły wcześniej i przedziałów czasu ich trwania",

możliwe staje opracowanie modeli matematycznych przydatnych do wartościującego opisu działania tego silnika $\mathrm{z}$ zastosowaniem teorii procesów semi-markowskich [3].

Przykład realizacji procesu $\{\mathrm{W}(\mathrm{t}): \mathrm{t} \in \mathrm{T}\}$ przedstawiono na rys. 1.

Graf stanów - przejść rozpatrywanego procesu $\{\mathrm{W}(\mathrm{t}): \mathrm{t} \in \mathrm{T}\} \mathrm{z}$ uwzględnieniem opisanych wyżej zjawisk zmian dawki i mocy można przedstawić ogólnie jak na rys. 2 .

Tym samym macierz funkcyjna $\mathrm{Q}_{\mathrm{ij}}(\mathrm{t})$ rozpatrywanego procesu ma (jak wynika z rys. 2) postać równania (4).

Elementy tej macierzy zależą od rozkładu zmiennych losowych, którymi są przedziały czasu przebywania procesu w wyróżnionych stanach - równanie (5), gdzie: $\mathrm{p}_{\mathrm{ij}}$ - prawdopodobieństwo przejścia ze stanu $\mathrm{s}_{\mathrm{i}}$ do stanu $\mathrm{s}_{\mathrm{j}}, \mathrm{F}_{\mathrm{ij}}(\mathrm{t})$ - dystry-

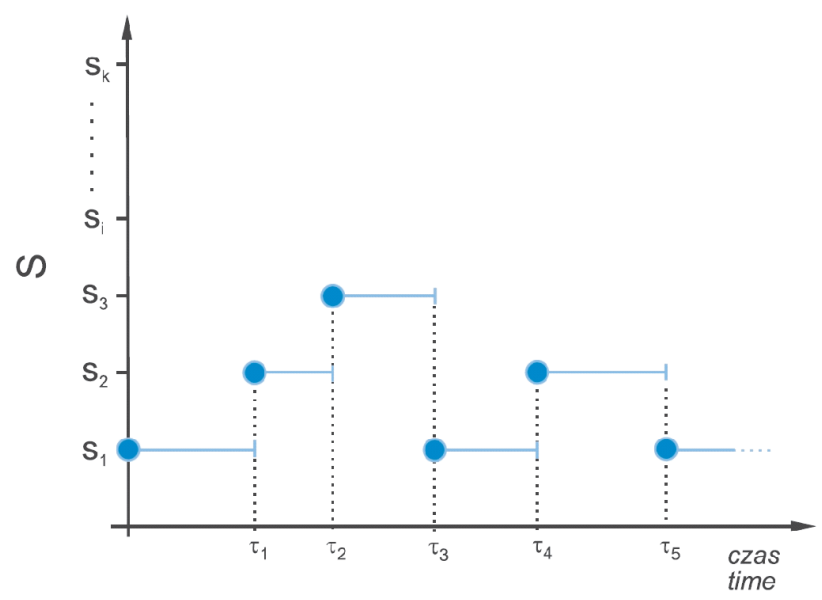

Fig. 1. Example of $\{\mathrm{W}(\mathrm{t}): \mathrm{t} \geq \mathrm{T}\}$ process realization Rys. 1. Przykład realizacji procesu $\{W(t): t \geq T\}$ 


$$
\begin{gathered}
\mathrm{p}_{1}=\mathrm{P}\left\{\mathrm{W}(0)=\mathrm{s}_{1}\right\}=1, \\
\mathrm{p}_{\mathrm{i}}=\mathrm{P}\left\{\mathrm{W}(0)=\mathrm{s}_{\mathrm{i}}\right\}=0 \\
\text { for } \mathrm{i}=2,3,4, \ldots, \mathrm{k}
\end{gathered}
$$

As much as the determination of the presented conditions is fully determined by the semi-Markov processes at the same time determining all its necessary characteristics (including the first transition) the applicable value of so defined process is rather limited.

This limitation results from the fact that it is difficult to verify the model and these difficulties are connected with the necessity to determine the parameters of the distribution functions of random variables $T_{i j}$ that describe the duration of state $\mathrm{s}_{\mathrm{i}}$ under the condition that the process passes to state $s_{j}$ and that the estimations of probabilities $\mathrm{p}_{\mathrm{ij}}$ presented in (5). These actions require an application of advanced diagnostic systems in the investigations that enable an identification of each of the possible $s_{i}$ states, which in practice can turn out to be very difficult or impossible to realize.

Hence, in order to boost the usability-related advantages of the presented model

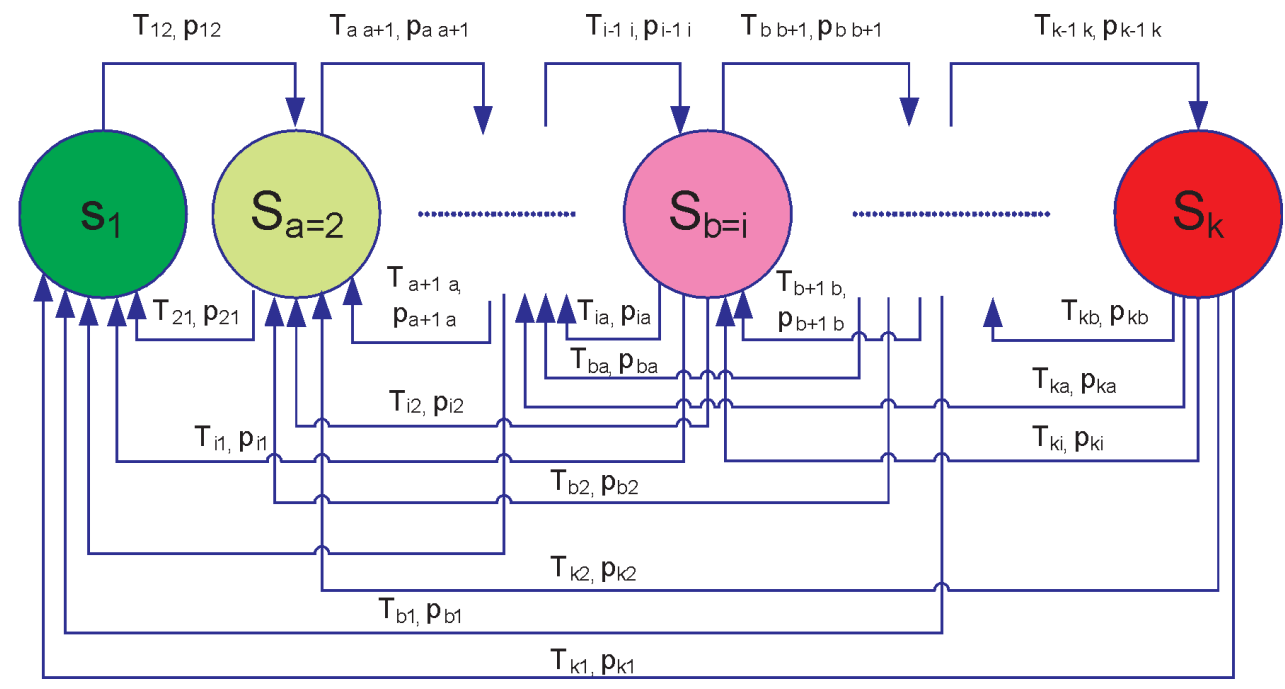

Fig. 2. Graph of states - transitions of $\{\mathrm{W}(\mathrm{t}): \mathrm{t} \in \mathrm{T}\}$ process. $\mathrm{s}_{\mathrm{a}}-$ state of engine in which increase of unit fuel consumption emerges without noticeable increase of $\mathrm{N}_{\mathrm{e}}$ value, $\mathrm{a}=2,3 \ldots, \mathrm{i}-1, \mathrm{~s}_{\mathrm{b}}-$ state of engine in which due to structural restrictions and lack of possibility to increase fuel dose, limitation in useful power developed by engine will appear, $\mathrm{b}=\mathrm{i}, \mathrm{i}+1, \ldots, \mathrm{k}-1, \mathrm{~s}_{\mathrm{k}}$ - state of engine in which due to degradation of structure, it's not used any more (no engine functioning - no operation)

Rys. 2. Graf stanów-przejść procesu $\{W(t): t \in T\}, s_{a}$-stan silnika, w którym następuje wzrost jednostkowego zużycia paliwa bez obserwowalnego zmniejszenia wartości $N_{e}, a=2,3 \ldots, i-1 ; s_{b}-$ stan silnika, w którym na skutek ograniczén konstrukcyjnych i braku możliwości zwiększenia dawki paliwa pojawi się ograniczenie w wartości mocy użytecznej rozwijanej przez silnik, $b=i, i+1, \ldots, k-1 ; s_{k}-$ stan silnika, w którym na skutek degradacji struktury przestaje być użtkowany (brak funkcjonowania silnika - brak działania) it seems necessary to simplify it so as to enable a verification using standard control-measurement systems that are usually fitted in the majority of marine engines. Such a verification will be possible provided there is a reduction of the set of possible process states to selected subsets of the classes of states significant in terms of engine operation and those possible to identify with the said systems.

\section{The reduction of the number of elements of the set of classes of states}

When considering the engine operation in the quantitative aspect from the practical point of view four sets of classes of states of the process presented in the previous point will be significant:

- Class of states s' ${ }_{1}$ - the engine in good technical conditions and in the state of full operativeness, there are no limitations related to it and the efficiency indicators reach the values assumed by the manufacturer,

- Class of states $s_{2}$ - the engine is not fully operative and is not ready for task completion, there are no limitations as to its parameters for loads not higher than the nominal loads and the efficiency indicators (unit fuel consumption)

Jakkolwiek ustalenie przedstawionych warunków określa całkowicie rozpatrywany proces semi-Markowa, umożliwiając tym samym wyznaczenie wszystkich niezbędnych jego charakterystyk (w tym również czas pierwszego przejścia), aplikacyjna wartość tak zdefiniowanego procesu jest dość ograniczona. Ograniczenie to wynika przede wszystkim z trudności weryfikacji modelu wiążących się z koniecznością wyznaczenia wartości parametrów dystrybuant zmiennych losowych $\mathrm{T}_{\mathrm{ij}}$, opisujących czas trwania stanu $\mathrm{s}_{\mathrm{i}}$ pod warunkiem przejścia procesu do stanu $\mathrm{s}_{\mathrm{j}}$ oraz oszacowań przedstawionych $\mathrm{w}$ zależności (5) prawdopodobieństw $\mathrm{p}_{\mathrm{ij}}$. Czynności te wymagają m.in. zastosowania $\mathrm{w}$ badaniach eksploatacyjnych zaawansowanych systemów diagnozujących, umożliwiających identyfikację każdego z możliwych stanów s, co w praktyce może okazać się bardzo trudne do realizacji lub wręcz niemożliwe.

W związku z powyższym, aby zwiększyć walory utylitarne przedstawionego modelu, wydaje się konieczne takie jego uproszczenie, które umożliwi weryfikację z zastosowaniem standardowych systemów kontrolno-pomiarowych, 
reach values that are different than those assumed by the manufacturer,

- Class of states $\mathrm{s}_{3}$ - the engine is not fully operative and is not ready for task completion, there are limitations as to its parameters for nominal and higher loads and the efficiency indicators (unit fuel consumption) reach values that are substantially different than those assumed by the manufacturer,

- Class of states s' ${ }_{4}$ - the engine is not fully operative and is not ready for task completion, the limitations of its parameters for a wide spectrum of loads makes it impossible to use the engine for purposes for which it was designed.

Thus, we can define a new semi-Markov process $\left\{\mathrm{W}^{\prime}(\mathrm{t})\right.$ : $\mathrm{t} \in \mathrm{T}\}$, whose graph of states - transitions will be as follows in Fig. 3.

Function matrix $\mathrm{Q}_{\mathrm{ij}}(\mathrm{t})$ of the analyzed process has the following form (as results from the graph):

$$
Q^{\prime}(\mathrm{t})=\left[\begin{array}{cccc}
0 & Q_{12}(\mathrm{t}) & 0 & 0 \\
Q_{21}^{\prime}(\mathrm{t}) & 0 & Q_{23}^{\prime}(\mathrm{t}) & 0 \\
Q^{\prime}{ }_{31}(\mathrm{t}) & Q_{32}^{\prime}(\mathrm{t}) & 0 & Q^{\prime}{ }_{34}(\mathrm{t}) \\
Q_{41}^{\prime}(\mathrm{t}) & Q_{42}^{\prime}(\mathrm{t}) & Q_{43}^{\prime}(\mathrm{t}) & 0
\end{array}\right]
$$

Eventually, the determination of the initial distribution of the process $\left\{W^{\prime}(t): t \in T\right\}$ (for example in the case of analysis of a fully operative engine) as:

$$
\begin{gathered}
\mathrm{p}_{1}=\mathrm{P}\left\{\mathrm{W}(0)=\mathrm{s}_{1}\right\}=1, \\
\mathrm{p}_{\mathrm{i}}=\mathrm{P}\left\{\mathrm{W}(0)=\mathrm{s}_{\mathrm{i}}\right\}=0 \text { dla } \mathrm{i}=2,3,4
\end{gathered}
$$

determines the whole analyzed process enabling the determination of its characteristics including one of the more important characteristic from the practical point of view- the distribution of time of the first transition of process $\left\{W^{\prime}(t)\right.$ : $\mathrm{t} \in \mathrm{T}\}$ to the distinguished subset of states. In the discussed situation the time when the process first reaches the given subsets of classes of states can be analyzed in three alternative variants that, if process $\left\{\mathrm{W}^{\prime}(\mathrm{t}): \mathrm{t} \in \mathrm{T}\right\}$ is recognized as a reliability model, can be deemed as states of inoperativeness in the reliability sense:

a) Transition from the class of states s' 1 to the subset of states $\left\{\mathrm{s}_{2}, \mathrm{~s}_{2}, \mathrm{~s}_{4}\right\}$,

b) Transition from the subset of the classes of states $\left\{\mathrm{s}_{1}\right.$, $\left.\mathrm{s}_{2}\right\}$ to the subset of the classes of states $\left\{\mathrm{s}_{3}, \mathrm{~s}_{4}\right\}$,

c) Transition from the subset of the classes of states $\left\{\mathrm{s}^{\prime}, \mathrm{s}_{2}\right.$, $\left.\mathrm{s}_{3}\right\}$ to the class of states $\left\{\mathrm{s}_{4}\right\}$.

Each of the above-presented variants represents a different decision-related situation where more or less restrictive limitations of the task realizations are considered as follows:

- In the situation presented in a) - the conditions of the task realization by the engine are formulated as the highest limitations because the subset of the classes of states deemed as states of inoperativeness contains all the classes but s',

- In the situation presented in b) - the conditions of the task realization by the engine are formulated taking into account będących na wyposażeniu większości siłowni okrętowych. Weryfikacja taka będzie możliwa pod warunkiem redukcji zbioru możliwych stanów procesu do wytypowanych podzbiorów klas stanów istotnych w aspekcie działania silnika oraz możliwych do identyfikacji z użyciem wymienionych systemów.

\section{Redukcja liczby elementów zbioru klas stanów}

Przy rozpatrywaniu działania silnika w ujęciu ilościowym z praktycznego punktu widzenia znaczenie będą mieć cztery podzbiory klas stanów procesu przedstawionego $\mathrm{w}$ poprzednim rozdz., a mianowicie:

- klasa stanów s' ${ }_{1}$ - silnik znajduje się w stanie sprawności technicznej i pełnej zdatności zadaniowej, nie występują żadne ograniczenia dotyczące jego parametrów użytkowych, a wskaźniki efektywności osiągają wartości założone przez producenta,

- klasa stanów s' ${ }_{2}$ - silnik znajduje się w stanie niesprawności technicznej i niepełnej zdatności zadaniowej, nie występują żadne ograniczenia dotyczące jego parametrów użytkowych dla obciążeń nie większych niż obciążenia nominalne, a wskaźniki efektywności (np. jednostkowe zużycie paliwa) osiągają wartości odbiegające od założonych przez producenta,

- klasa stanów s' ${ }_{3}$ - silnik znajduje się w stanie niesprawności technicznej i niepełnej zdatności zadaniowej, pojawiają się ograniczenia dotyczące jego parametrów użytkowych dla obciążeń zbliżonych do nominalnych i większych, a wskaźniki efektywności (np. jednostkowe zużycie paliwa) osiągają wartości znacznie odbiegające od założonych przez producenta,

- klasa stanów s' ${ }_{4}$ - silnik znajduje się w stanie niesprawności technicznej i niezdatności zadaniowej, ograniczenia dotyczące jego parametrów użytkowych dla szerokiego spektrum obciążeń uniemożliwiają zastosowanie silnika zgodnie z jego przeznaczeniem.

Można tym samym zdefiniować nowy proces semimarkowski $\left\{\mathrm{W}^{\prime}(\mathrm{t}): \mathrm{t} \in \mathrm{T}\right\}$, którego graf stanów - przejść przedstawiono na rys. 3 .

Macierz funkcyjna $Q_{i j}(t)$ rozpatrywanego procesu ma (jak wynika z grafu) postać równania (8).

Ostatecznie określenie rozkładu początkowego procesu $\left\{\mathrm{W}^{\prime}(\mathrm{t}): \mathrm{t} \in \mathrm{T}\right\} \mathrm{np} . \mathrm{W}$ przypadku rozpatrywania silnika $\mathrm{W}$ stanie sprawności technicznej i pełnej zdatności zadaniowej jako (9)

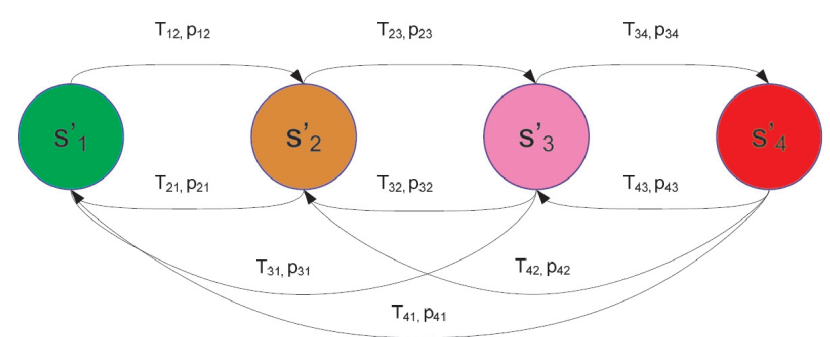

Fig. 3. States - transitions graph of $\left\{\mathrm{W}^{\prime}(\mathrm{t}): \mathrm{t} \in \mathrm{T}\right\}$ process Rys. 3. Graf stanów przejść procesu $\left\{W^{\prime}(t): t \in T\right\}$ 
the usability limitations i.e. the subset of classes of states deemed as inoperative contains the classes of states $\mathrm{s}_{3}$ and $\mathrm{s}_{4}$,

- In the situation presented in c) - the conditions of the task realization by the engine are formulated in the most tolerant way, irrespective of the usability limitations (also the time of the task realization) and the costs of its performance related to the increased fuel consumption (the subset of the classes of states deemed as inoperative contains only class s' ${ }_{4}$ ).

\section{The time of the first transition of the process to the subset of the classes of states}

The probability of engine being placed in a given class of states can be determined based on the distribution and parameters of the time of the first transition of process $\left\{\mathrm{W}^{\prime}(\mathrm{t})\right.$ : $t \in T\}$ to a distinguished subset of states.

Based on [2] if $\mathrm{N} \subset \mathrm{S}$ - denotes the set of states deemed as the states of inoperativeness and $\mathrm{N}^{\prime}=\mathrm{S}-\mathrm{A}-$ the set of states of its operativeness then the Laplace transform of the probability density of random variable $\Xi_{\mathrm{iN}}$ - denoting time that elapses from the moment of the assumption by process $\left\{\mathrm{W}^{\prime}(\mathrm{t}): \mathrm{t} \geq 0\right\}$ of the value $\mathrm{i} \in \mathrm{N}^{\prime}$ until a moment when the process assumes any value from the subset of states $\mathrm{N}$ will be the solution of the equation:

where:

$$
\widetilde{\varphi}_{N^{\prime}}(s)=\left[I-\widetilde{q}_{N^{\prime}}(s)\right]^{-1} \cdot \widetilde{b}(s)
$$

$$
\begin{gathered}
\left.\widetilde{\mathrm{q}}_{\mathrm{N}^{\prime}}(\mathrm{s})=\tilde{\mathrm{q}}_{\mathrm{ij}}(\mathrm{s})\right\rfloor_{\mathrm{wxw}} \quad \mathrm{i}, \mathrm{j} \in \mathrm{N}^{\prime}=\left\{\mathrm{i}_{1}, \mathrm{i}_{2}, \ldots, \mathrm{i}_{\mathrm{w}}\right\} \\
\widetilde{\varphi}_{\mathrm{N}^{\prime}}(\mathrm{s})=\left[\begin{array}{c}
\sum_{\mathrm{j} \in \mathrm{N}} \widetilde{\mathrm{q}}_{\mathrm{i}_{1} \mathrm{j}}(\mathrm{s}) \\
\widetilde{\varphi}_{\mathrm{i}_{2} \mathrm{~N}}(\mathrm{~s}) \\
\vdots \\
\widetilde{\varphi}_{\mathrm{i}_{\mathrm{w}} \mathrm{N}}(\mathrm{s})
\end{array}\right] \tilde{\mathrm{b}}(\mathrm{s})=\left[\begin{array}{c}
\sum_{\mathrm{j} \in \mathrm{N}} \widetilde{\mathrm{q}}_{\mathrm{i}_{2} \mathrm{j}}(\mathrm{s}) \\
\vdots \\
\sum_{\mathrm{j} \in \mathrm{N}} \widetilde{\mathrm{q}}_{\mathrm{i}_{\mathrm{w}} \mathrm{j}}(\mathrm{s})
\end{array}\right]
\end{gathered}
$$

This probability should be determined in the first place in two situations from the practical point of view:

1. If the subset of the classes of states of inoperativeness $\mathrm{N}$ is determined as follows:

$$
\mathrm{N}=\left\{\mathrm{s}_{3}, \mathrm{~s}_{4}\right\}
$$

In this situation the time of the task realization is important hence the user does not allow any potential limitations of the usability-related properties at the same time accepting the possible higher costs of the task realization.

2. If the subset of the classes of states $\mathrm{N}$ is determined as follows:

$$
\mathrm{N}=\left\{\mathrm{s}_{4}\right\} .
$$

in this situation the task realization is important and the time of its completion and costs are of secondary importance (a scenario possible to accept in a situation when the safety of the vessel is compromised).

If the subset of the classes of states of inoperativeness $\mathrm{N}$ is determined in this way:

thus:

$$
\mathrm{N}=\left\{\mathrm{s}_{3}, \mathrm{~s}_{4}{ }_{4}\right\}
$$

określa całkowicie rozpatrywany proces, umożliwiając tym samym wyznaczenie jego charakterystyk, w tym również jedną z ważniejszych z praktycznego punktu widzenia - rozkład czasu I przejścia procesu $\left\{W^{\prime}(t): t\right.$ $\in \mathrm{T}\}$ do wyróżnionego podzbioru stanów. W omawianej sytuacji czas pierwszego osiągnięcia przez proces określonych podzbiorów klas stanów można rozpatrywać w trzech alternatywnych wariantach, które w razie uznania procesu $\left\{\mathrm{W}^{\prime}(\mathrm{t}): \mathrm{t} \in \mathrm{T}\right\}$ za model niezawodnościowy mogą być uznane za stany niezdatności w sensie niezawodnościowym:

a) przejście z klasy stanów s', do podzbioru stanów $\left\{\mathrm{s}_{2}, \mathrm{~s}_{2}{ }_{2}\right.$, $\left.\mathrm{s}_{4}\right\}$

b) przejście z podzbioru klas stanów $\left\{\mathrm{s}_{1}, \mathrm{~s}_{2}\right\}$ do podzbioru klas stanów $\left\{\mathrm{s}_{3}, \mathrm{~s}_{4}\right\}$,

c) przejście z podzbioru klas stanów $\left\{\mathrm{s}_{1}, \mathrm{~s}_{2}, \mathrm{~s}_{3}{ }_{3}\right\}$ do klasy stanów $\left\{\mathrm{s}_{4}\right\}$.

Każdy z przedstawionych wyżej wariantów reprezentuje odmienną sytuację decyzyjną, w której brane są pod uwagę mniej lub bardziej restrykcyjne ograniczenia warunków realizacji zadania:

- w sytuacji przedstawionej w pkt. a) - warunki realizacji zadania przez silnik sformułowane są w sposób największych ograniczeń, ponieważ podzbiór klas stanów uznanych za stany niezdatności zawiera wszystkie klasy z wyjątkiem klasy s',

- w sytuacji przedstawionej w pkt. b) - warunki realizacji zadania przez silnik sformułowane są z uwzględnieniem wyłącznie ograniczeń użytkowych, tzn. podzbiór klas stanów uznanych za stany niezdatności zawiera klasy stanów s' ${ }_{3}$ oraz s',

- w sytuacji przedstawionej w pkt. c) - warunki realizacji zadania przez silnik sformułowane są w sposób najbardziej tolerancyjny, bez względu na ograniczenia użytkowe (czyli również czas realizacji zadania) oraz podwyższone koszty jego wykonania związane ze zwiększonym zużyciem paliwa (podzbiór klas stanów uznanych za stany niezdatności zawiera tylko klasę $\left.\mathrm{s}_{4}\right)$.

\section{Czas I przejścia procesu do podzbioru klas stanów}

Prawdopodobieństwo przebywania silnika w określonej klasie stanów można wyznaczyć, opierając się na rozkładzie i parametrach czasu pierwszego przejścia rozpatrywanego procesu $\left\{\mathrm{W}^{\prime}(\mathrm{t}): \mathrm{t} \in \mathrm{T}\right\}$ do wyodrębnionego podzbioru stanów.

Na podstawie [2], jeżeli $\mathrm{N} \subset \mathrm{S}$ oznacza zbiór stanów uznanych za stany niezdatności, zaś $\mathrm{N}^{`}=\mathrm{S}-\mathrm{A}-$ zbiór stanów jego zdatności, to transformata Laplace’a gęstości prawdopodobieństwa zmiennej losowej $\Xi_{\mathrm{iN}}$ - oznaczającej czas, który upływa od chwili przyjęcia przez proces $\left\{\mathrm{W}^{\prime}(\mathrm{t})\right.$ : $\mathrm{t} \geq 0\}$ wartości $\mathrm{i} \in \mathrm{N}^{`}$ do chwili, w której proces przyjmie jakąkolwiek wartość z podzbioru stanów N, będzie rozwiązaniem równania (10), gdzie poszczególne wielkości oznaczono wzorami (11) i (12).

Prawdopodobieństwo to wydaje się celowym, z praktycznego punktu widzenia, do wyznaczenia w pierwszej 


$$
\mathrm{N}^{\prime}=\left\{\mathrm{s}_{1}, \mathrm{~s}_{2}\right\},
$$

relations (11) and (12) are as follows:

$$
\begin{aligned}
& \widetilde{\mathrm{q}}_{\mathrm{N}^{\prime}}(\mathrm{s})=\left[\begin{array}{cc}
0 & \widetilde{\mathrm{q}}_{12}(\mathrm{~s}) \\
\widetilde{\mathrm{q}}_{12}(\mathrm{~s}) & 0
\end{array}\right] \\
\text { - } & \widetilde{\varphi}_{\mathrm{N}^{\prime}}(\mathrm{s})=\left[\begin{array}{c}
\widetilde{\varphi}_{13-4}(\mathrm{~s}) \\
\widetilde{\varphi}_{23-4}(\mathrm{~s})
\end{array}\right] \\
\widetilde{\mathrm{b}}(\mathrm{s}) & =\left[\begin{array}{c}
0 \\
\widetilde{\mathrm{q}}_{23}(\mathrm{~s})
\end{array}\right]
\end{aligned}
$$

where: $\widetilde{\mathrm{q}}_{N^{\prime}}(\mathrm{s})$ - Laplace transform of the derivative of the elements of function matrix of process $\mathrm{Q}_{\mathrm{ij}}(\mathrm{t}), \widetilde{\varphi}_{13-4}(\mathrm{~s})-\mathrm{La}-$ place transform of the probability density of random variable $\Xi_{13-4}$ denoting time that elapses from the assumption by process $\left\{W^{\prime}(t): t \geq 0\right\}$ of state s', until the process assumes a state of s' ${ }_{3}$ or s' ${ }_{4}, \widetilde{\varphi}_{23-4}(\mathrm{~s})$ - Laplace transform of the probability density of random variable $\Xi_{23-4}$ denoting time that elapses from the assumption by process $\left\{\mathrm{W}^{\prime}(\mathrm{t}): \mathrm{t} \geq 0\right\}$ of state $\mathrm{s}_{2}$, until the process assumes a state of $\mathrm{s}_{3}{ }_{3}$ or $\mathrm{s}_{4}$.

Equation (10) in this case will take a form:

$$
\left[\begin{array}{c}
\widetilde{\varphi}_{13-4}(\mathrm{~s}) \\
\widetilde{\varphi}_{23-4}(\mathrm{~s})
\end{array}\right]=\left[\left[\begin{array}{cc}
1 & 0 \\
0 & 1
\end{array}\right]-\left[\begin{array}{cc}
0 & \widetilde{\mathrm{q}}_{12}(\mathrm{~s}) \\
\widetilde{\mathrm{q}}_{21}(\mathrm{~s}) & 0
\end{array}\right]\right]^{-1} \cdot\left[\begin{array}{c}
0 \\
\widetilde{\mathrm{q}}_{23}(\mathrm{~s})
\end{array}\right]
$$

Having performed the calculations and carried out the Laplace inverse translation, the distribution function of random variables $\Xi_{13-4}$ and $\Xi_{23-4}$ :

$$
\begin{aligned}
& \Phi_{13-4}(\mathrm{t})=\int_{0}^{\mathrm{t}}\left[\varphi_{13-4}(\mathrm{t})\right] \mathrm{t}, \\
& \Phi_{23-4}(\mathrm{t})=\int_{0}^{\mathrm{t}}\left[\varphi_{23-4}(\mathrm{t})\right] \mathrm{t},
\end{aligned}
$$

allow determining of the functions $R_{13-4}(t)$ and $R_{23-4}(t)$ :

$$
\begin{aligned}
& \mathrm{R}_{13-4}(\mathrm{t})=1-\int_{0}^{\mathrm{t}}\left[\rho_{13-4}(\mathrm{t})\right] \mathrm{t} \\
& \mathrm{R}_{23-4}(\mathrm{t})=1-\int_{0}^{\mathrm{t}}\left[\varphi_{13-4}(\mathrm{t})\right] \mathrm{t}
\end{aligned}
$$

that enable the determination of the discussed probabilities of transition of the engine state to $\mathrm{s}_{3} \cup \mathrm{s}_{4}$ depending on its current assumed state.

If the subset of the classes of states of inoperativeness $\mathrm{N}$ is determined as follows: thus:

$$
\mathrm{N}=\left\{\mathrm{s}_{4}\right\},
$$

$$
\mathrm{N}^{\prime}=\left\{\mathrm{s}_{1}, \mathrm{~s}_{2}, \mathrm{~s}_{3}{ }_{3}\right\},
$$

The relations (11) and (12) take the following form:

$$
\widetilde{\mathrm{q}}_{\mathrm{N}^{\prime}}(\mathrm{s})=\left[\begin{array}{ccc}
0 & \widetilde{\mathrm{q}}_{12}(\mathrm{~s}) & 0 \\
\widetilde{\mathrm{q}}_{12}(\mathrm{~s}) & 0 & \widetilde{\mathrm{q}}_{23}(\mathrm{~s}) \\
\widetilde{\mathrm{q}}_{31}(\mathrm{~s}) & \widetilde{\mathrm{q}}_{32}(\mathrm{~s}) & 0
\end{array}\right]
$$

kolejności w dwóch sytuacjach:

1. Jeżeli podzbiór klas stanów niezdatności $\mathrm{N}$ określony jest: $\mathrm{N}=\left\{\mathrm{s}_{3}, \mathrm{~s}_{4}\right\}$.

W sytuacji tej istotny jest czas realizacji zadania, w związku z czym użytkownik nie dopuszcza potencjalnych ograniczeń właściwości użytkowych silnika $\mathrm{z}$ jednoczesną akceptacją ewentualnie wyższych kosztów jego wykonania.

2. Jeżeli podzbiór klas stanów niezdatności $\mathrm{N}$ określony jest: $\mathrm{N}=\left\{\mathrm{s}_{4}\right\}$.

W sytuacji tej istotne jest przede wszystkim wykonanie zadania, przy czym czas jego realizacji oraz koszty odgrywają rolę drugorzędną (scenariusz możliwy do zaakceptowania np. w sytuacji zagrożenia bezpieczeństwa statku).

Jeżeli podzbiór klas stanów niezdatności $\mathrm{N}$ określony jest: $\mathrm{N}=\left\{\mathrm{s}_{3}, \mathrm{~s}_{4}\right\}$, a tym samym: $\mathrm{N}^{\prime}=\left\{\mathrm{s}_{1}, \mathrm{~s}_{2}\right\}$, zależności (11) oraz (12) przedstawiają się w postaci (13)-(15), gdzie: $\widetilde{\mathrm{q}}_{\mathrm{N}^{\prime}}(\mathrm{s})$ - transformata Laplace'a pochodnej elementów macierzy funkcyjnej procesu $\mathrm{Q}_{\mathrm{ij}}^{\prime}(\mathrm{t}), \widetilde{\varphi}_{13-4}(\mathrm{~s})$ - transformata Laplace'a gęstości prawdopodobieństwa zmiennej losowej $\Xi_{13-4}$ oznaczającej czas, który upływa od chwili przyjęcia przez proces $\left\{\mathrm{W}^{\prime}(\mathrm{t}): \mathrm{t} \geq 0\right\}$ stanu $\mathrm{s}^{\prime}$, do chwili, w której proces przyjmie stan s' ${ }_{3}$ lub s' ${ }_{4}, \widetilde{\varphi}_{23-4}(\mathrm{~s})$ - transformata Laplace'a gęstości prawdopodobieństwa zmiennej losowej $\Xi_{23-4}$ oznaczającej czas, który upływa od chwili przyjęcia przez proces $\left\{\mathrm{W}^{\prime}(\mathrm{t}): \mathrm{t} \geq 0\right\}$ stanu $\mathrm{s}_{2}$, do chwili, $\mathrm{w}$ której proces przyjmie stan $\mathrm{s}_{3}$ lub s'.

Równanie (10) przyjmie wtedy postać równania (16).

Po wykonaniu stosownych obliczeń oraz dokonaniu odwrotnego przekształcenia Laplace'a dystrybuanty zmiennych losowych $\Xi_{13-4}$ oraz $\Xi_{23-4}$ przedstawione w postaci (17) i (18) pozwalają określić funkcje $R_{13-4}(t)$ oraz $R_{23-4}(t) w$ postaci równań (19) i (20), które pozwalają określić rozpatrywane prawdopodobieństwa przejścia silnika do stanu s' ${ }_{3} \cup \mathrm{s}_{4}{ }_{4} \mathrm{~W}$ zależności od zakładanego jego stanu aktualnego.

Jeżeli podzbiór klas stanów niezdatności $\mathrm{N}$ określony jest: $\mathrm{N}=\left\{\mathrm{s}_{4}{ }_{4}\right\}$, a tym samym: $\mathrm{N}^{\prime}=\left\{\mathrm{s}_{1}, \mathrm{~s}_{2}, \mathrm{~s}_{3}{ }_{3}\right.$, zależności (11) oraz (12) przedstawiają się następująco - równania (21)-(23), gdzie: $\widetilde{\mathrm{q}}_{\mathrm{N}^{\prime}}(\mathrm{s})$ - transformata Laplace'a pochodnej elementów macierzy funkcyjnej procesu $\mathrm{Q}_{\mathrm{ij}}(\mathrm{t}), \widetilde{\varphi}_{14}(\mathrm{~s})$ - transformata Laplace'a gęstości prawdopodobieństwa zmiennej losowej $\Xi_{14}$ oznaczającej czas, który upływa od chwili przyjęcia przez proces $\left\{W^{\prime}(t): t \geq 0\right\}$ stanu $s^{\prime}$, do chwili, w której proces przyjmie stan s', $\widetilde{\varphi}_{24}(\mathrm{~s})$ - transformata Laplace'a gęstości prawdopodobieństwa zmiennej losowej $\Xi_{24}$ oznaczającej czas, który upływa od chwili przyjęcia przez proces $\left\{\mathrm{W}^{\prime}(\mathrm{t}): \mathrm{t} \geq 0\right\}$ stanu $\mathrm{s}^{\prime}{ }_{2}$, do chwili, W której proces przyjmie stan $\mathrm{s}_{4}, \widetilde{\oplus}_{34}(\mathrm{~s})$ - transformata Laplace'a gęstości prawdopodobieństwa zmiennej losowej $\Xi_{34}$ oznaczającej czas, który upływa od chwili przyjęcia przez proces $\left\{\mathrm{W}^{\prime}(\mathrm{t}): \mathrm{t} \geq 0\right\}$ stanu $\mathrm{s}^{\prime}{ }_{3}$, do chwili, w której proces przyjmie stan $\mathrm{s}_{4}$.

Równanie (10) przyjmie w tym przypadku postać równania (24).

Po wykonaniu stosownych obliczeń oraz dokonaniu odwrotnego przekształcenia Laplace'a dystrybuanty zmiennych losowych $\Xi_{14}, \Xi_{24}$ oraz $\Xi_{34}$ mają postać równań (25)-(27), 


$$
\begin{array}{r}
-\quad \widetilde{\varphi}_{\mathrm{N}^{\prime}}(\mathrm{s})=\left[\begin{array}{c}
\widetilde{\varphi}_{14}(\mathrm{~s}) \\
\widetilde{\varphi}_{24}(\mathrm{~s}) \\
\widetilde{\varphi}_{34}(\mathrm{~s})
\end{array}\right] \\
\widetilde{b}(\mathrm{~s})=\left[\begin{array}{c}
0 \\
0 \\
\widetilde{q}_{34}(\mathrm{~s})
\end{array}\right]
\end{array}
$$

where: $\widetilde{\mathrm{q}}_{\mathrm{N}^{\prime}}(\mathrm{s})$ - Laplace transform of the derivative of the elements of the function matrix of process $Q^{\prime}(\mathrm{t}), \widetilde{\varphi}_{14}(\mathrm{~s})$ - Laplace transform of the probability density of random variable $\Xi_{14}$ denoting time that elapses from the moment process $\left\{W^{\prime}(t): t \geq 0\right\}$ assumes state $s^{\prime}$, until the moment the process assumes state $s_{4}, \widetilde{\varphi}_{24}(s)$ - Laplace transform of the probability density of random variable $\Xi_{24}$ denoting time that elapses from the assumption by process $\left\{W^{\prime}(t)\right.$ : $\mathrm{t} \geq 0$ \} of state $\mathrm{s}_{2}$, until the process assumes a state of $\mathrm{s}^{\prime}{ }_{4}$, $\widetilde{\varphi}_{34}(\mathrm{~s})$ - Laplace transform of the probability density of random variable $\Xi_{34}$ denoting time that elapses from the assumption by process $\left\{\mathrm{W}^{\prime}(\mathrm{t}): \mathrm{t} \geq 0\right\}$ of state $\mathrm{s}_{3}{ }_{3}$, until the process assumes a state of $\mathrm{s}_{4}{ }_{4}$.

Equation (10) in this case takes a form of:

$$
\left[\begin{array}{c}
\widetilde{\varphi}_{14}(\mathrm{~s}) \\
\widetilde{\varphi}_{24}(\mathrm{~s}) \\
\widetilde{\varphi}_{34}(\mathrm{~s})
\end{array}\right]=\left[\left[\begin{array}{ccc}
1 & 0 & 0 \\
0 & 1 & 0 \\
0 & 0 & 1
\end{array}\right]-\left[\begin{array}{ccc}
0 & \widetilde{\mathrm{q}}_{12}(\mathrm{~s}) & 0 \\
\widetilde{\mathrm{q}}_{21}(\mathrm{~s}) & 0 & \widetilde{\mathrm{q}}_{23}(\mathrm{~s}) \\
\widetilde{\mathrm{q}}_{31}(\mathrm{~s}) & \widetilde{\mathrm{q}}_{32}(\mathrm{~s}) & 0
\end{array}\right]\right]^{-1} \cdot\left[\begin{array}{c}
0 \\
0) \\
\widetilde{\mathrm{q}}_{34}(\mathrm{~s})
\end{array}\right](24)
$$

Having performed the calculations and carried out the Laplace inverse translation, the distribution function of the random variables $\Xi_{14}, \Xi_{24}$ and $\Xi_{34}$ :

$$
\begin{aligned}
& \Phi_{14}(\mathrm{t})=\int_{0}^{\mathrm{t}}\left[\varphi_{14}(\mathrm{t})\right] \mathrm{dt}, \\
& \Phi_{24}(\mathrm{t})=\int_{0}^{\mathrm{t}}\left[\varphi_{24}(\mathrm{t})\right] \mathrm{dt}, \\
& \Phi_{34}(\mathrm{t})=\int_{0}^{\mathrm{t}}\left[\varphi_{34}(\mathrm{t})\right] \mathrm{tt},
\end{aligned}
$$

allows determining of functions $R_{14}(t), R_{24}(t)$ and $R_{34}(t)$ :

$$
\begin{aligned}
& \mathrm{R}_{14}(\mathrm{t})=1-\int_{0}^{\mathrm{t}}\left[\varphi_{14}(\mathrm{t})\right] \mathrm{dt}, \\
& \mathrm{R}_{24}(\mathrm{t})=1-\int_{0}^{\mathrm{t}}\left[\varphi_{24}(\mathrm{t})\right] \mathrm{dt}, \\
& \mathrm{R}_{34}(\mathrm{t})=1-\int_{0}^{\mathrm{t}}\left[\varphi_{34}(\mathrm{t})\right] \mathrm{t},
\end{aligned}
$$

that, in turn, allow determining of the analyzed probabilities of the engine transition to state $\mathrm{s}_{4}{ }_{4}$ depending on the assumed current engine state.

As results from equations (16) and (24) the vital issue when determining of the functions of density of the discussed random variables is the knowledge of the analytical form of the elements of the function matrix of process $Q^{\prime}{ }_{i j}(t)$. pozwalają określić funkcje $\mathrm{R}_{14}(\mathrm{t}), \mathrm{R}_{24}(\mathrm{t})$ oraz $\mathrm{R}_{34}(\mathrm{t})$ za pomocą równań (28)-(30),

które pozwalają określić rozpatrywane prawdopodobieństwa przejścia silnika do stanu s' ${ }_{4} \mathrm{~W}$ zależności od zakładanego jego stanu aktualnego.

Jak wynika z równań (16) i (24) sprawą kluczową podczas wyznaczania poszukiwanych funkcji gęstości omawianych zmiennych losowych jest znajomość analitycznej postaci elementów macierzy funkcyjnej procesu $\mathrm{Q}_{\mathrm{ij}}{ }_{\mathrm{j}}(\mathrm{t})$.

Jej znalezienie umożliwia wykorzystanie zależności [3] (31), gdzie: $p_{i j}$ - prawdopodobieństwo przejścia ze stanu s' ${ }_{i}$ do stanu s' ${ }_{j}$ włożonego w proces semi-Markowa, łańcucha Markowa (i, j $\in \mathrm{S}$ ), przy czym do oszacowania poszczególnych prawdopodobieństw $\mathrm{p}_{\mathrm{ij}}$ najwygodniej przyjąć (na podstawie wyników badań empirycznych) statystykę w postaci (32), gdzie: $n_{i j}$ - liczba przejść procesu ze stanu s' ${ }_{i}$ do stanu $s^{\prime}{ }_{j}(i, j \in S, i \neq j), F_{i j}(t)-$ dystrybuanta zmiennej losowej $\mathrm{T}_{\mathrm{ij}}$ oznaczającej czas trwania $\mathrm{s}{ }_{\mathrm{i}}$ - tego stanu procesu, pod warunkiem, że następnym stanem będzie stan $s^{\prime}{ }_{j}$-ty.

\section{Zastosowanie charakterystyk czasu I przejścia procesu do podzbioru klas stanów}

Praktyczne wykorzystanie funkcji opisanych zależnościami (19)-(20) lub (28)-(30) przedstawione może być na podstawie przykładowej, hipotetycznej sytuacji decyzyjnej, w której użytkownik ze względu na istniejące ograniczenia zewnętrzne (armatorskie) za kryterium nadrzędne przyjmuje czas realizacji zadania, w związku z czym nie dopuszcza potencjalnych ograniczeń właściwości użytkowych silnika z jednoczesną akceptacją ewentualnie wyższych kosztów jego wykonania (zbiór stanów niezdatności $\mathrm{N}=\left\{\mathrm{s}_{3}, \mathrm{~s}_{4}{ }_{4}\right\}$ ).

$\mathrm{Z}$ formalnego punktu widzenia procedurę decyzyjną wygodnie jest w tej sytuacji przedstawić w jednej z najczęściej spotykanych strukturalnych postaci: drzewa lub tablicy decyzyjnej. Obie techniki są w zasadzie równoważne, w związku z czym dalsze rozważania prowadzone są na podstawie techniki drzew decyzyjnych.

Przykładowe drzewo decyzyjne przedstawiono na rys. 4.

Funkcją kryterium dla przedstawionego drzewa jest maksymalizacja wartości oczekiwanej konsekwencji $\mathrm{c}\left(\mathrm{d}_{\mathrm{j}}, \mathrm{s}_{\mathrm{i}}\right)$, którą dla poszczególnych węzłów drzewa symbolizujących podjęcie wybranej decyzji $\mathrm{d}_{\mathrm{j}}$ można określić [5] na podstawie równania (33).

Zastosowanie przedstawionej na rys. 4 procedury decyzyjnej, oprócz określenia repertuaru możliwych do podjęcia decyzji, wymaga dysponowania wiedzą, umożliwiającą: specyfikację wyróżnionych stanów (klas stanów) procesu, oszacowanie konsekwencji $-\mathrm{c}\left(\mathrm{d}_{\mathrm{j}}, \mathrm{s}_{\mathrm{i}}{ }^{\prime}\right)$ oraz wyznaczenie wartości prawdopodobieństw warunkowych $-\mathrm{p}\left(\mathrm{s}_{\mathrm{i}}{ }_{\mathrm{i}}\right) / \mathrm{d}_{\mathrm{j}}$. W tym zakresie przydatny staje się przedstawiony w niniejszym opracowaniu model.

W sytuacji podjęcia decyzji $\mathrm{d}_{1}$ (realizacja zadania po wykonaniu obsługi) można $\mathrm{z}$ dużym prawdopodobieństwem założyć, że rozkład początkowy procesu $\left\{\mathrm{W}^{\prime}(\mathrm{t}): \mathrm{t} \geq 0\right\}$ określony jest zależnością (9), a tym samym do wyznaczenia wartości prawdopodobieństw warunkowych $\mathrm{p}\left(\mathrm{s}_{\mathrm{i}}{ }_{\mathrm{i}} / \mathrm{d}_{1}\right)$ zasto- 
Finding it allows using relation [3]:

$$
Q^{\prime}{ }_{i j}(t)=p_{i j} \cdot F_{i j}(t)
$$

where: $p_{i j}$ - probability of the engine transition from state $s$, to state $s^{\prime}{ }_{j}$ put in the semi Markov process, Markov's chain $(i, j \in S)$ and for the evaluation of the individual probabilities pij it is most convenient to assume (based on the empirical test results) the following statistics:

$$
p_{i j}^{*}=\frac{n_{i j}}{\sum_{j} n_{i j}}
$$

where: $n_{i j}-$ the number of transitions of the process from state $s^{\prime}{ }_{i}$ to state $s^{\prime}{ }_{j}(i, j \in S, i \neq j), F_{i j}(t)$ - distribution function of random variable $T_{i j}$ denoting the duration of $s{ }_{i}-$ of this process state provided that the next one is $s^{\prime}$.

\section{The application of the characteristics of the time of the first transition of the process to the subset of classes of states}

A practical use of the functions described with relations (19)-(20) or (28) - (30) can be presented based on the example of a hypothetical decisionmaking situation in which the user, due to the existing external limitations (shipowner's limitations) will see the time of the task completion as the criterion of utmost importance, hence he will not assume potential limitations of the usability-related properties at the same accepting the possible higher costs of the operation (the set of states of inoperativeness $\mathrm{N}=\left\{\mathrm{s}_{3}, \mathrm{~s}_{4}\right\}$ ).

From the formal point of view it is convenient to represent the decision making procedure in one of the most frequent structural forms: a tree or decision table. Both techniques are equivalent in principle and that is why further considerations are continued based on the techniques of decision-making trees.

In the presented case the decision making tree is as shown in Fig. 4.

The criterion function for the presented tree is the maximization of the value of the expected consequence $c\left(d_{j}, s_{i}\right)$ that (for the individual nodes of the tree denoting the taken decision $\mathrm{d}_{\mathrm{j}}$ ) can be described as follows [5]:

$$
\begin{aligned}
& E\left(c / d_{j}\right)=\sum_{i=1}^{k}\left[p\left(s_{i}^{\prime}\right) / d_{j} \cdot c\left(d_{j}, s_{i}^{\prime}\right)\right] \\
& i=1,2,3,4 \quad j=1,2
\end{aligned}
$$

sować zależności opisujące rozkład chwilowy lub graniczny procesu $\left\{\mathrm{W}^{\prime}(\mathrm{t}): \mathrm{t} \geq 0\right\}[3]$.

$\mathrm{W}$ razie podjęcia decyzji $\mathrm{d}_{2}$ (realizacja zadania bez wykonania obsługi) rozkład początkowy procesu jest $\mathrm{w}$ zasadzie nieznany - wykluczając z oczywistych względów przynależność do jednego ze stanów klas s' ${ }_{3}$ lub s'. Tym samym zamiast hipotetycznie zakładać możliwe warianty tego rozkładu (w celu zastosowania rozkładu chwilowego/granicznego procesu) bardziej odpowiednim postępowaniem prowadzącym do wyznaczenia wartości prawdopodobieństw warunkowych $\mathrm{p}\left(\mathrm{s}_{\mathrm{i}} / \mathrm{d}_{1}\right)$ - wydaje się zastosowanie rozkładu czasu I przejścia procesu, a więc do określenia wartości prawdopodobieństwa $\mathrm{p}\left(\mathrm{s}_{1}{ }_{1}\right) / \mathrm{d}_{2}$ zastosować zależność (17) zaś wartości prawdopodobieństwa $\mathrm{p}\left(\mathrm{s}_{2}{ }_{2}\right) / \mathrm{d}_{2}-$ zależność (18).

\section{Podsumowanie}

Teoria procesów semi-markowskich dostarcza wielu użytecznych metod i narzędzi przydatnych w badaniach obiektów technicznych. Procesy semi-markowskie jako modele rzeczywistych procesów eksploatacji np. silników okrętowych wydają się przydatne również w aspekcie ilościowego opisu działania, co wynika przede wszystkim z tego, że w przypadku rozpatrywania procesów o ciągłym

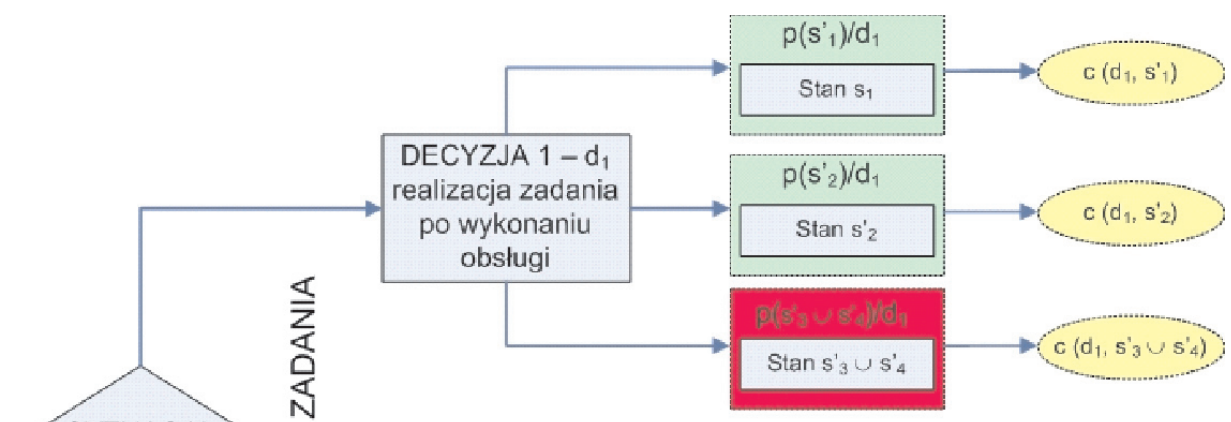

Fig. 4. Example of decision tree. $\mathrm{p}\left(\mathrm{s}_{\mathrm{j}}\right) / \mathrm{d}_{\mathrm{j}}$ - conditional probability of occurrence of the state $\mathrm{s}_{\mathrm{i}}$ in the case of taking the decision $\mathrm{d}_{\mathrm{j}} ; \mathrm{c}\left(\mathrm{d}_{\mathrm{j}}, \mathrm{s}_{\mathrm{i}}\right)$ - consequence of occurrence of the state si in the case of taking the decision $\mathrm{d}_{\mathrm{j}}$

Rys. 4. Przykład drzewa decyzyjnego. $p\left(s_{i}\right) / d_{j}$ - prawdopodobieństwo osiagnięcia stanu $s_{i}$ pod warunkiem podjęcia decyzji $d_{j} ; c\left(d_{j}, s_{i}\right)$ - konsekwencje wystapienia stanu $s_{i} w$ sytuacji podjęcia decyzji $d_{j}$

parametrze czasu i skończonym zbiorze stanów przedziały przebywania tych procesów w poszczególnych stanach są zmiennymi losowymi o dowolnych rozkładach.

Prezentowana metoda wydaje się cennym uzupełnieniem stosowanych do tej pory sposobów opisu cech niezawodnościowych tak istotnego podsystemu siłowni (i statku), jakim jest układ napędowy. Jej podstawowa zaleta to powiązanie oceny energetycznej z czasem, w którym jest realizowane 
The application of the decision-making procedure presented in Fig. 4 apart from the determining of the range of the possible decisions requires knowledge that enables: the specification of the distinguished states (classes of states) of the process, evaluation of the consequences $-\mathrm{c}\left(\mathrm{d}_{\mathrm{j}}, \mathrm{s}_{\mathrm{i}}\right)$ and determining of the values of conditional probabilities $-\mathrm{p}\left(\mathrm{s}_{\mathrm{i}}{ }_{\mathrm{i}}\right) \mathrm{d}_{\mathrm{j}}$. In this respect the here presented model seems useful.

If decision $\mathrm{d}_{1}$ is taken (realization of the task after servicing) with a high level of probability we can assume that the initial distribution of process $\left\{\mathrm{W}^{\prime}(\mathrm{t}): \mathrm{t} \geq 0\right\}$ is determined with relation (9) thus in order to determine the values of the conditional probabilities $\mathrm{p}\left(\mathrm{s}_{\mathrm{i}} / \mathrm{d}_{1}\right)$ we can use the relations that describe instantaneous or boundary distribution of process $\left\{\mathrm{W}^{\prime}(\mathrm{t}): \mathrm{t} \geq 0\right\}$ [3].

If decision $\mathrm{d}_{2}$ is taken (realization of the task without servicing) the initial distribution is virtually unknown - for obvious reasons excluding the affinity to one of the states of classes s' ${ }_{3}$ or s'. Instead of hypothetically assuming the possible variants of this distribution (in order to use the instantaneous/boundary process) a more suitable action leading to the determining of the value of the conditional probabilities $\mathrm{p}\left(\mathrm{s}^{\prime}{ }_{i} / \mathrm{d}_{1}\right)$ would be the use of the distribution of the time of the process - for the determining of probability $\mathrm{p}\left(\mathrm{s}_{1}{ }_{1}\right) /$ $\mathrm{d}_{2}-$ the relation (17) and probability $\mathrm{p}\left(\mathrm{s}_{2}{ }_{2}\right) / \mathrm{d}_{2}$ relation (18).

\section{Conclusions}

The theory of the semi-Markov processes provides a variety of useful methods in the testing of technical objects. The semi-Markov processes as models of real operation processes of marine engines for example also seem useful in terms of qualitative description of the operation, which results from the fact that in the case of analysis of processes of a continuous parameter of time and a finite set of states the ranges of the processes being set in individual states are random variables of any given distributions.

The here presented method seems a valuable supplement of the so far applied methods of description of the reliability related properties of such an important subsystem of the vessel propulsion (including the vessel) as the drivetrain. Its basic advantage is the connection of the energy evaluation with time in which the task is realized (the time is very important when realizing long lasting marine tasks).

Using this method at any given moment $t$ we can determine the effective power (effective energy) that can be realized by the whole drivetrain and determine the probability of occurrence of such a number of events that will cause additional limitations while performing a task (through an impossibility of a free selection of the vessel speed) or will render the task undoable. The value of this probability can thus be treated as the value of a reliability indicator and can be used when taking operation related decisions.

Its additional advantage is its universality in the sense that it can be used for the analysis of any marine device or energy subsystem including devices that are not machines such as heat exchangers. zadanie, który ma bardzo istotne znaczenie przy realizacji długotrwałych z reguły morskich zadań transportowych.

Korzystając z niej, można dla dowolnej chwili t określić pracę użyteczną (energię użyteczną), jaka może być wykonana przez cały układ napędowy oraz określić wartość prawdopodobieństwa pojawienia się takiej liczby zdarzeń, które spowodują powstanie dodatkowych ograniczeń podczas realizacji zadania (przez brak możliwości dowolnej realizacji prędkości pływania) lub jego uniemożliwienie. Wartość tego prawdopodobieństwa może $\mathrm{w}$ związku $\mathrm{z}$ tym być traktowana jako wartość wskaźnika niezawodnościowego i wykorzystana podczas podejmowania decyzji eksploatacyjnych.

Dodatkową jej zaletą jest uniwersalność, powodująca, iż może być zastosowana do analizy niezawodności każdego okrętowego urządzenia lub podsystemu energetycznego, w tym również dla urządzeń niebędących maszynami, jak np. wymienników ciepła.

Paper reviewed/Artykut recenzowany

\section{Bibliography/Literatura}

[1] Girtler J., Kuszmider S., Plewiński L.: Wybrane zagadnienia eksploatacji statków morskich w aspekcie bezpieczeństwa żeglugi. WSM, Szczecin 2003.

[2] Grabski F.: Czas pierwszego przejścia procesu semi-Markowa do podzbioru stanów. Zeszyty Naukowe WSMW nr 3, Gdynia 1981.

[3] Grabski F.: Teoria semi-markowskich procesów eksploatacji obiektów technicznych. Zeszyty Naukowe AMW, nr 75A, Gdynia 1982.

[4] Rudnicki J.: Działanie systemu energetycznego w ujęciu wartościującym z uwzględnieniem jego struktury niezawodnościowej oraz stopnia zużycia potencjału użytkowego. Praca wykonana w ramach projektu finansowanego przez MNiSW Nr N509 045 31/3500. Projekt badawczy pt.: Kształtowanie bezpieczeństwa działania systemów energetycznych środków transportowych na przykładzie systemów okrętowych. Gdańsk 2008.

[5] Sadowski W.: Teoria podejmowania decyzji. Państwowe Wydawnictwo Ekonomiczne. Warszawa 1976.

Jacek Rudnicki, DEng. - doctor in the Faculty of Ocean Engineering and Ship Technology at Gdansk University of Technology.

Dr inż. Jacek Rudnicki - adiunkt na Wydziale Oceanotechniki i Okrętownictwa Politechniki Gdańskiej.

e-mail: jacekrud@pg.gda.pl 